\title{
Tingkat Pengembalian Investasi Pendidikan Tinggi Lulusan Program Studi STEM (Science, Technology, Engineering, dan Mathematics)
}

\section{Return on Investment in Higher Education for Graduates of STEM (Science, Technology, Engineering, and Mathematics) Study Programs}

\author{
Esti Wahyu Perdani ${ }^{1)}$, Padang Wicaksono ${ }^{2)}$ \\ Fakultas Ekonomi dan Bisnis, Universitas Indonesia, Kota Depok \\ e-mail korespondensi: esti.wahyu@bps.go.id
}

\begin{tabular}{|l|}
\hline Info Artikel \\
\hline Riwayat Artikel : \\
Diterima: 09 April 2021 \\
Disetujui: 05 Juli 2021 \\
Dipublikasikan: Januari 2022 \\
\hline Nomor DOI \\
10.33059/jseb.v13i1.3420 \\
Cara Mensitasi : \\
Perdani, E. W., \& Wicaksono, \\
P. (2022). Tingkat \\
pengembalian investasi \\
pendidikan tinggi lulusan \\
program studi STEM (Science, \\
technology, engineering dan \\
mathematics). Jurnal Samudra \\
Ekonomi dan Bisnis, 13(1), \\
28-45. doi: 10.33059/ \\
jseb.v13i1.3420
\end{tabular}

\begin{abstract}
Abstrak
Penelitian ini bertujuan menganalisis tingkat pengembalian investasi pendidikan tinggi lulusan program studi STEM dengan menggunakan data Survei Angkatan Kerja Nasional (SAKERNAS) tahun 2019. Penelitian ini menggunakan metode Ordinary Least Square (OLS) dengan pendekatan two step Heckman. Hasilnya adalah tingkat pengembalian investasi pendidikan lulusan STEM tertinggi terjadi pada jenjang pendidikan S2 serta tingkat pengembalian investasi pendidikan lulusan STEM perempuan lebih tinggi daripada laki-laki. Program studi STEM memiliki stereotipe yaitu program studi dengan biaya yang mahal dan syarat akan maskulinitas maka dari itu perlu adanya peningkatan jumlah beasiswa terutama pada program pascasarjana dan pemberian kesempatan yang sama pada laki-laki dan perempuan untuk bersekolah dan bekerja pada bidang STEM.
\end{abstract}

Kata Kunci: Tingkat Pengembalian Investasi Pendidikan, STEM Education, Fungsi Pendapatan Mincerian, Two Step Heckman, Sheepskin Effect.

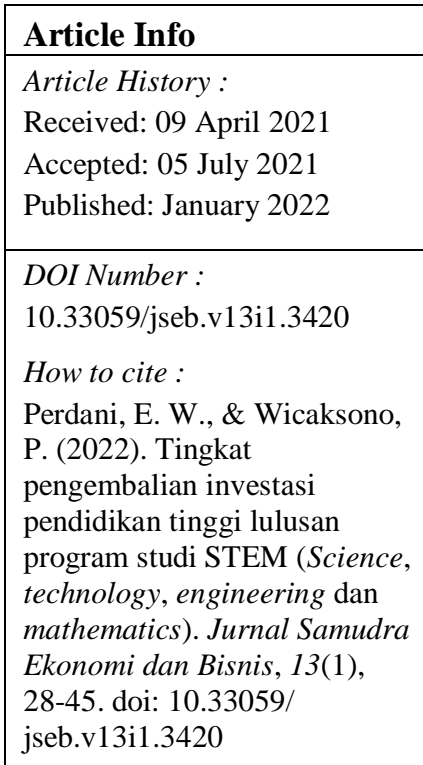

\section{Abstract}

This study aims to analyze the rate of return on investment in higher education for graduates of STEM study programs using data from the 2019 National Labor Force Survey (SAKERNAS). This study uses the Ordinary Least Square $(O L S)$ method with a two-step Heckman approach. The result is that the highest rate of return on investment for STEM graduates occurs at the master's level and the rate of return on investment for female STEM graduates is higher than that of men. STEM study programs have a stereotype, namely study programs with expensive costs and requirements for masculinity, therefore it is necessary to increase the number of scholarships, especially in postgraduate programs and provide equal opportunities for men and women to study and work in the STEM field.

Keywords: Returns to Investment in Education, STEM Education, Mincerian Earning Function, Two Step Heckman, Sheepskin Effect. 


\section{PENDAHULUAN}

Pendidikan baik yang bersifat formal maupun informal merupakan salah satu investasi modal manusia yang penting baik bagi individu secara pribadi maupun bagi negara, selain kesehatan dan migrasi (Schultz, 1961). Pendidikan tidak hanya memberikan manfaat kepada siswa dengan bertambahnya pengetahuan namun juga merupakan suatu investasi yang bisa bermanfaat meningkatkan pendapatan di masa depan (Daly et al., 2015). Semakin tinggi pendidikan diharapkan dapat meningkatkan kualitas sumber daya manusia dan akhirnya meningkatkan produktivitas ketika memasuki pasar kerja. Peningkatan produktivitas tenaga kerja akan menyebabkan peningkatan pertumbuhan ekonomi (Schultz, 1961; Lee et al., 2019), dimana hal ini sangat diharapkan oleh semua negara terutama Indonesia yang sedang memasuki era Bonus Demografi.

Pengintegrasian bidang-bidang science, technology, engineering, and mathematics (STEM) telah menjadi isu global dalam dunia pendidikan. Istilah Pendidikan STEM mengacu pada pembelajaran dan pengajaran di bidang Science, Technology, Engineering, dan Mathematics yang mencakup semua tingkat kelas baik yang dilakukan secara formal maupun informal (Gonzales \& Kuenzi, 2014). Pada tahun 1990, Pendidikan STEM diperkenalkan oleh Departemen Pendidikan Amerika Serikat (AS) sebagai tema dari reformasi pendidikan AS yang kini telah diadopsi oleh negara-negara lain diseluruh dunia sebagai dasar dari inovasi pendidikan. Indonesia juga mulai mengadopsi pendidikan berbasis STEM dalam kurikulum 2013 dengan memasukkan unsur saintifik dalam pembelajaran di kelas (Khairani et al., 2018).

Pada level pendidikan tinggi, berbasis klasifikasi program instruksional departemen pendidikan AS yang termasuk bidang studi STEM adalah bidang studi yang mengajarkan ilmu biologi atau biomedis, ilmu fisika, teknisi atau teknisi sains, sains komputer dan informasi dan layanan pendukung, statistik atau matematika, teknik, teknologi teknik, profesi kesehatan atau residensi medis, program sains pertanian atau sumber daya alam, atau studi terkait. Secara umum, bidang terkait mencakup bidang yang melibatkan penelitian, inovasi, ataupun pengembangan teknologi baru menggunakan ilmu teknik, matematika, kesehatan, ilmu komputer, atau ilmu alam termasuk ilmu fisika, biologi, dan pertanian (Department of Homeland Security, 2016; VeteransAffairs, 2020).

Dibandingkan jurusan pendidikan non STEM, mahasiswa yang terdaftar pada jurusan STEM lebih sedikit. Berdasarkan data kementrian Riset, Teknologi, dan Pendidikan Tinggi (Kemenristekdikti) tahun 2019, ada 63,2 persen mahasiswa berkuliah pada jurusan non STEM (Gambar 1) dimana sebagian besar mahasiswa itu berkuliah pada jurusan pendidikan, ekonomi maupun sosial (Kemenristekdikti, 2019).

Keinginan pemerintah Indonesia untuk mencetak lebih banyak lulusan perguruan tinggi di bidang STEM untuk memenuhi kebutuhan SDM di era revolusi Industri 4.0 yaitu dengan mengeluarkan surat edaran nomor 2/M/SE/IX/2016 mengenai pendirian perguruan tinggi baru dan pembukaan program studi (Ristekdikti, 2017). Pemerintah melakukan moratorium pendirian perguruan tinggi yang menyelenggarakan pendidikan akademik terkecuali pendirian program perguruan tinggi vokasi dan institut teknologi serta program studi di bidang STEM.

Melalui implementasi jenis pendidikan berbasis STEM diharapkan timbul gerakan global yang dapat menjembatani antara kebutuhan pasar kerja dengan ketersediaan keahlian yang diperlukan untuk pembangunan ekonomi pada abad ke-21 (Firman, 2016). Penelitian di berbagai negara juga memper- 
lihatkan pentingnya tipe pendidikan berbasis STEM bagi peningkatan kualitas sumber daya manusia (SDM) yang pada akhirnya dapat berkontribusi bagi kemajuan bangsa (Kharas \& Kohli, 2011; Ray, 2015; Paweenawat \& Vechbanyongratana, 2015; Lee et al., 2019).

Pendidikan STEM dianggap sebagai dasar pertumbuhan ekonomi di berbagai negara (Lee et al., 2019). Pendidikan STEM menjadi faktor penting dalam terciptanya inovasi ilmiah dan adaptasi teknologi. Penelitian yang dilakukan oleh Ray (2015) menyatakan bahwa share dari lulusan STEM berhubungan positif dengan pertumbuhan Produk Domestik Bruto (PDB) riil per kapita. Selain itu, peningkatan share lulusan STEM dapat meningkatkan hak paten yang disetujui. Artinya, semakin meningkat share dari lulusan STEM maka dapat meningkatkan kinerja ekonomi serta innovasi ilmiah. Lulusan STEM diharapkan mampu berdaya saing di era revolusi Industri 4.0.

Pendidikan STEM yang telah diterapkan mulai dari pendidikan dasar di negara-negara Asia timur menyebabkan negara-negara Asia Timur seperti Jepang, Taiwan, dan Korea Selatan dalam satu abad bisa bermetamorfosis dari low income menjadi middle income dan akhirnya menjadi high income country tanpa hambatan berarti dan dapat terhindar dari middle income trap (Kharas \& Kohli, 2011; Paweenawat \& Vechbanyongratana, 2015).
Di dunia kerja, pencapaian kerja di bidang STEM erat kaitanya dengan daya saing dan innovasi yang diciptakan oleh suatu negara. Banyak negara berinvestasi besar pada bidang STEM dan menjadikan bidang ini berkembang pesat dalam beberapa dekade (Shin et al., 2018). Pada era revolusi industri 4.0 tiap negara berlomba untuk menciptakan sumber daya mausia yang unggul yang dapat bersaing di tingkat global. Namun kekurangan lulusan STEM masih menjadi isu di berbagai negara (Paweenawat \& Vechbanyongratana, 2015; Smith et al., 2017). Hasil riset dari World Economic Forum tahun 2016 bahwa China adalah negara pencetak lulusan STEM tertinggi yaitu sebesar 4,7 juta lulusan disusul India sebesar 2,6 juta lulusan sedangkan Indonesia hanya sebesar 206 ribu lulusan.

Di Indonesia, perubahan penggunaan teknologi seperti robotik dan otomatisasi yang akan mengubah perusahaan dan penggunaan pekerja dalam proses produksi dalam dua dekade kedepan (ILO, 2017). International Labour Organization (ILO) mengestimasi bahwa lebih dari 56 persen pekerjaan (lebih dari 60 juta pekerjaan) akan menghadapi resiko otomatisasi. Tantangan ke depan yang dihadapi adalah kebutuhan akan tenaga kerja dengan keahlian tinggi dan spesifik yang memiliki tidak hanya hard-skill (terutama pada ilmu sains ketekhnikan) tetapi juga softskill yang mumpuni (Hadiat, 2020).

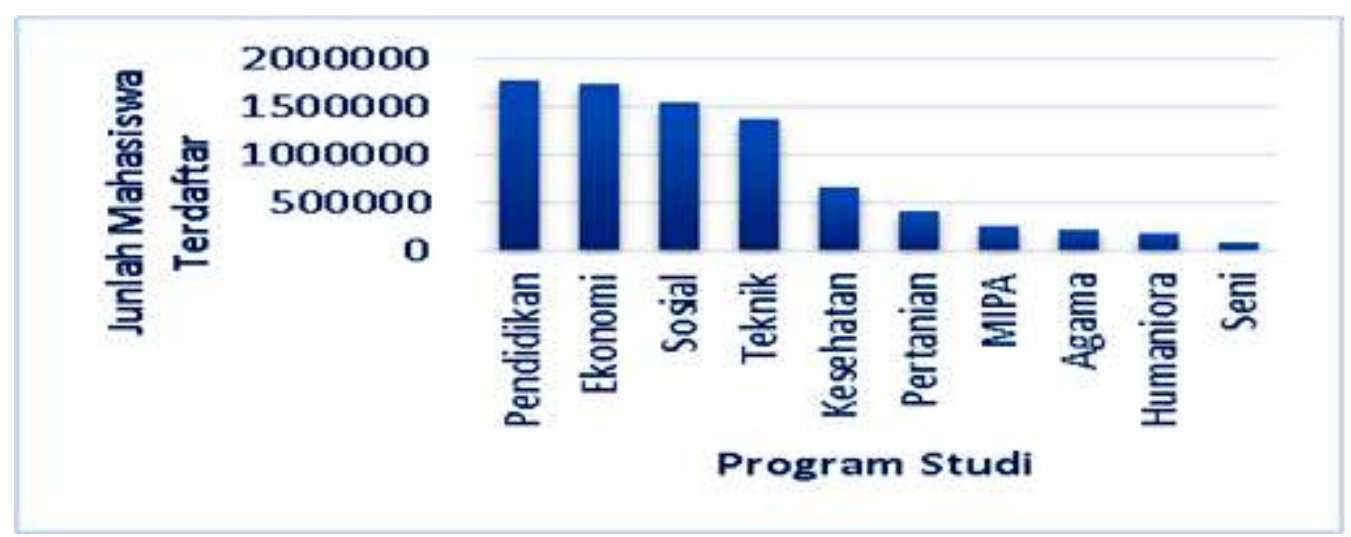

Gambar 1. Jumlah Mahasiswa Terdaftar Tahun 2019 Berdasarkan Program Studi

Sumber: Statistik Pendidikan Tinggi Indonesia, 2019. 
Stereotipe yang menyatakan bahwa teknologi merupakan bagian dari maskulinitas menyebabkan pengembangannya diidentikkan dengan kaum laki-laki (LIPI, 2018). Jumlah lulusan Perguruan Tinggi (PT) jurusan Teknologi Informasi dan Komunikasi (TIK) masih didominasi oleh laki-laki dimana pada tahun 2015 jumlah lulusan PT jurusan TIK sebesar 73,60\% adalah laki-laki (LIPI, 2018). Pelaku TIK pada sektor pemerintah juga didominasi oleh kaum laki-laki dimana persentase peneliti di lembaga pemerintah dengan kepakaran TIK sebesar 66,23 persen adalah kaum laki-laki.

Berbagai studi menyatakan perempuan tidak bisa berpartisipasi dalam kegiatan ilmu pengetahuan dan teknologi karena berbagai faktor seperti kemiskinan, tidak bersekolah formal hingga jenjang pendidikan tinggi serta faktor lain seperti politik, budaya, lingkungan dan kebijakan pemerintah yang tidak berpihak pada keterlibatan perempuan dalam iptek (UNESCO, 2007). Berdasarkan data Survei Angkatan Kerja Nasional (SAKERNAS) tahun 2019, juga terlihat bahwa tingkat keaktifan dalam pasar kerja lebih besar lakilaki daripada perempuan. Jumlah perempuan yang tidak masuk dalam angkatan kerja juga lebih banyak daripada laki-laki.

Pekerja dengan keahlian lebih spesifik mendapatkan pendapatan yang lebih tinggi daripada pekerja dengan keahlian umum (Black et al., 2003). Berdasarkan data SAKERNAS tahun 2019 bahwa pekerja lulusan STEM memiliki rata-rata pendapatan yang lebih tinggi daripada pekerja lulusan non STEM dan Pekerja lulusan STEM laki-laki memiliki rata-rata pendapatan lebih tinggi daripada pekerja lulusan STEM perempuan di semua level pendidikan. Namun demikian, tingkat pengangguran terbuka lulusan STEM laki-laki lebih tinggi daripada yang dirasakan kaum perempuan.
Menurut Todaro \& Smith (2011), dalam mengambil keputusan melanjutkan jenjang pendidikan dipengaruhi oleh dua faktor utama yaitu prospek pekerjaan di masa depan dengan jurusan pendidikan yang diambil, dan biaya pendidikan yang harus ditanggung. Investasi di pendidikan tinggi STEM lebih mahal jika dibandingkan dengan bidang studi lain (Nelson, 2008) menjadikan peminat jurusan STEM lebih sedikit dibandingkan non STEM. Rata-rata pendapatan pekerja lulusan STEM laki-laki lebih tinggi dari pendapatan pekerja perempuan lulusan STEM tidak menjamin tingkat pengembalian investasi pendidikan juga meningkat (Nurteta, 2016).

Penelitian tentang investasi pendidikan telah banyak dilakukan dengan menggunakan berbagai karakteristik namun sejauh yang mampu penulis telusuri, penelitian terkait pengembalian investasi pendidikan tinggi lulusan STEM di Indonesia masih terbatas. Penelitian ini berfokus menganalisis tingkat pengembalian investasi pendidikan tinggi lulusan STEM yang kemudian dilihat juga tingkat pengembalian investasi pendidikan berdasarkan gender, yaitu apakah tingkat pengembalian investasi pendidikan tinggi pekerja lulusan STEM laki-laki lebih tinggi daripada perempuan.

\section{Pendidikan Sebagai Investasi Modal Modal Manusia}

Modal manusia merupakan istilah yang sering digunakan oleh para ekonom untuk mengacu pada pendidikan, kesehatan, dan kapasitas manusia lainnya yang jika ditingkatkan akan meningkatkan produktivitas (Todaro \& Smith, 2011). Teori Modal Manusia adalah aliran pemikiran yang menganggap manusia merupakan modal atau kapital seperti kapital yang lainnya (tanah, teknologi, mesin, uang serta sebagainya) dan level pertumbuhannya memberikan dampak paling besar terhadap pendapatan nasional negara (Schultz, 1961). 
Adanya peningkatan dari pendapatan yang dihasilkan seseorang merupakan hasil dari investasi. Dengan berinvestasi pada diri sendiri, seseorang dapat memperbesar pilihan yang tersedia bagi dirinya demi peningkatan kesejahteraan (Schultz, 1961). Peningkatan level kesejahteraan terjadi karena adanya peningkatan sumber daya manusia yang diperoleh melalui sekolah dan dalam program pelatihan sambil bekerja formal maupun informal (Borjas, 2016).

Borjas (2016) berargumen keputusan seorang pekerja melanjutkan pendidikan tinggi daripada bekerja terjadi ketika present value dari pendapatan seumur hidup ketika mencapai pendidikan perguruan tinggi $\left(P V_{C o l}\right)$ melebihi present value dari jumlah pendapatan seumur hidup saat hanya memiliki ijazah sekolah menengah $\left(P V_{S H}\right)$ atau

$$
P V_{C O l}>P V_{S H}
$$

Pilihan seseorang untuk melanjutkan pendidikan ke jenjang yang lebih tinggi juga dipengaruhi oleh pendidikan orang tua dan pengeluaran rumah tangga (Ranti, 2015). Pilihan jurusan STEM untuk melanjutkan pendidikan tinggi dipengaruhi kemampuan kognitif. Penelitian oleh Wang (2013) bahwa memilih jurusan STEM dipengaruhi oleh prestasi matematika di SMA dan pengalaman awal setelah masuk SMA serta penerimaan bantuan keuangan. Faktor demografis seperti jenis kelamin dan etnis juga dinilai turut mempengaruhi (Crisp et al., 2009).

Tingkat pengembalian biasa diukur dengan analisis biaya-manfaat dari seluruh biaya yang dikeluarkan selama melakukan investasi pendidikan (Todaro \& Smith, 2011). Sehingga dapat disimpulkan bahwa tingkat pengembalian investasi pendidikan adalah perbandingan antara total biaya yang dikeluarkan untuk membiayai pendidikan dengan manfaat ataupun pendapatan yang diperoleh setelah menyelesaikan pendidikan.
Mincer (1974) mengestimasi biaya dan manfaat dari pendidikan bagi individu melalui model yang mengukur tingkat pengembalian investasi pendidikan, yang dikenal dengan Fungsi Pendapatan Mincer atau Mincerian Earning Function, yaitu:

$$
\text { Ln } \mathrm{Y}=b_{0}+b_{1} \mathrm{~S}+b_{2} A+b_{3} \mathrm{~A}^{2}
$$

Pendapatan dinotasikan sebagai $\ln (\mathrm{Y})$ dipengaruhi oleh lama sekolah (S), umur atau pengalaman bekerja (A), serta pengalaman bekerja yang dikuadratkan $\left(\mathrm{A}^{2}\right) ; b_{0}$ adalah parameter menunjukkan pendapatan individu tanpa memperhatikan tingkat pendidikan; $b_{1}$ yaitu level pengembalian investasi pendidikan individu (private rate of return to education); $b_{2}$ merupakan tingkat pengembalian dari pengalaman bekerja; dan $b_{3}$ adalah tingkat pengembalian dari pengalaman bekerja yang dikuadratkan. Tingkat pengembalian dari pendidikan atau koefisien $b_{1}$ dapat diinterpretasikan sebagai besaran tambahan pendapatan tiap ada peningkatan unit pendidikan.

Individu yang berpartisipasi pada pasar kerja dihadapkan pada pilihan antara bekerja dan tidak bekerja. Ada dua hal yang harus diputuskan individu dalam penawaran tenaga kerja, yaitu: (1) keputusan untuk ikut berpartisipasi dalam pasar kerja atau tidak; dan, (2) keputusan untuk menentukan berapa banyak waktu yang disediakan di pasar kerja jika memutuskan berpartisipasi. Banyak sedikitnya waktu yang digunakan untuk bekerja juga tergantung dari upah yang ditawarkan pada pasar kerja. Jika upah yang ditawarkan sama atau lebih tinggi dari reservation wage maka seseorang bersedia untuk bekerja (Borjas, 2016).

\section{Teori Segregasi Pekerjaan dan Feminist}

Teori segregasi pekerjaan menyatakan bahwa terjadi pemisahan pekerjaan antar gender (Beller, 2018). Terdapat beberapa 
pekerjaan yang didominasi oleh laki-laki seperti pekerjaan dibidang pertambangan dan konstruksi; sebaliknya, ada juga pekerjaan yang didominasi perempuan seperti guru dan perawat. Teori feminist menempatkan posisi perempuan berada dibawah laki-laki baik dalam masyarakat maupun keluarga. Di lingkungan masyarakat umumnya, perempuan memiliki memiliki peran untuk mengurus anak dan rumahtangga; sedangkan laki-laki berkewajiban mencari nafkah. Perempuan yang berpartisipasi dalam pasar kerja pada umumnya memiliki peran ganda sehingga cenderung menghasilkan pendapatan yang lebih rendah daripada laki-laki.

\section{STEM}

Menurut Roberts \& Cantu (2012), ada tiga pendekatan yang bisa diterapkan dalam

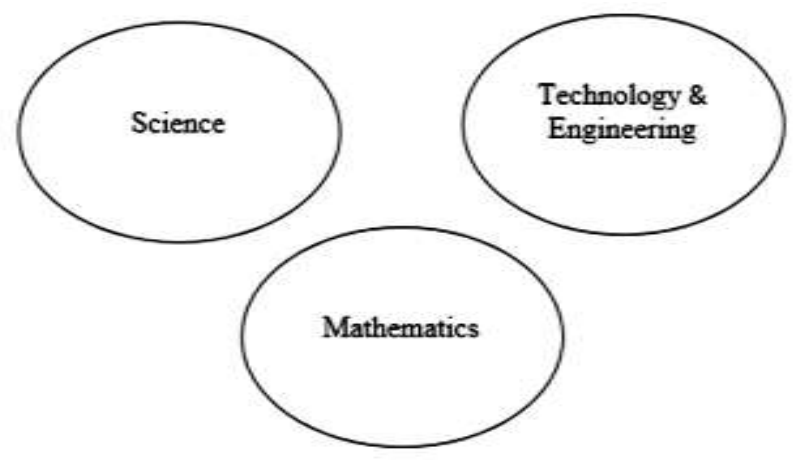

(a) Pendekatan SILO pembelajaran berbasis STEM di kelas. Perbedaan dalam ketiga pendekatan ini adalah pada kandungan STEM yang digunakan tiap pendekatan. Ketiga pendekatan ini adalah pendekatan SILO, pendekatan Tertanam (Embedded Approach), serta pendekatan Terpadu (Integrated Approach).

Pada pendekatan SILO, keempat unsur STEM, yaitu Science, Technology, Engineering, dan Mathematics, diajarkan secara terpisah. Mahasiswa bisa mempelajari tiaptiap unsur STEM secara mandalam, namun aspek ketrampilan akan kurang terasah. Mahasiswa hanya akan mendapatkan materi perkuliahan saja tanpa bisa mengaplikasikan pada aktivitas kehidupan sehari-hari. Model pendekatan SILO pada pembelajaran berbasis STEM ditunjukkan pada Gambar 2(a).

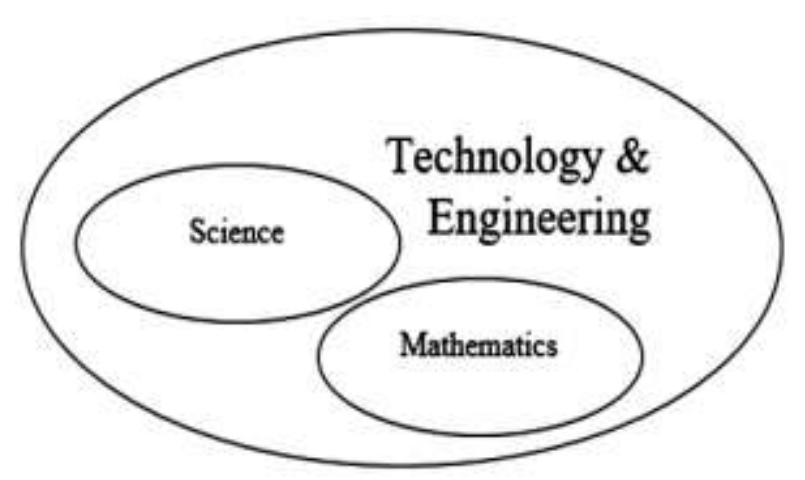

(b) Pendekatan Tertanam

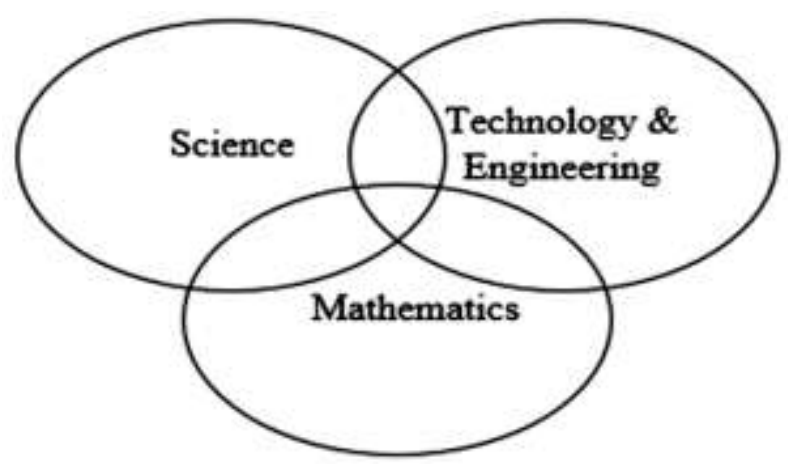

(c) Pendekatan Terpadu

\section{Gambar 2. Tiga Pendekatan dalam STEM}

Sumber: Roberts \& Cantu, 2012. 
Gambar 2(b) menunjukkan pendekatan Tertanam pada pembelajaran berbasis STEM. Pendekatan tertanam lebih fokus pada salah satu unsur STEM saja dan unsur yang lain dijadikan sebagai pelengkap. Pengetahuan mahasiswa akan lebih mendalam pada salah satu unsur STEM namun tidak pada unsur yang lainnya. Sebagai misal, pembelajaran STEM dengan pendekatan tertanam pada teknologi dan mesin atau engineering, maka unsur-unsur sains dan matematika dijadikan sebagai pelengkap wawasan dari materi perkuliahan yang digunakan menunjukkan penggunaan engineering pada kehidupan sehari-hari.

Pembelajaran dengan model pendekatan Terpadu, sebagaimana yang juga ditunjukkan dalam Gambar 2(c), lebih mudah untuk diterapkan pada jenjang pendidikan dasar. Hal ini karena terjadinya keterpaduan di antara tiap unsur STEM dalam proses pembelajaran. Pendekatan terpadu dinilai lebih mudah diterapkan pada jenjang pendidikan dasar sedangkan pendekatan tertanam lebih sesuai jika diterapkan pada jenjang pendidikan menengah dan tinggi. Pendekatan tertanam lebih sesuai untuk tingkat pendidikan tinggi karena mahasiswa telah memiliki ketertarikan terhadap jurusan masing-masing sehingga cara yang bisa dilakukan adalah menanamkan konsep dasar atau teori terkait unsur STEM ke dalam pembelajaran STEM lainnya. Misalnya dalam mata kuliah kalkulus, maka unsur sains (S), technology (T), engineering (E) diberikan pada konsep kalkulus, sehingga mahasiswa dapat lebih memahami dan mengaplikasikan kalkulus pada kehidupan sehari-hari.

Pengkategorian bidang studi STEM sering didasarkan atas keperluan penelitan, Webber (2014) serta Walker \& Zhu (2011) menggolongkan jurusan pendidikan tinggi yang termasuk jurusan STEM adalah ilmu biologi, ilmu komputer dan informasi, teknik, profesi kesehatan, matematika, dan ilmu fisika. Pada penelitian ini, pengklasifikasian jurusan STEM berdasarkan pada daftar program studi bidang STEM yang ada pada Laporan Akhir Sistem Ekonomi Nasional 2018 dan Keputusan Direktur Jenderal Pendidikan Tinggi Kementrian Pendidikan dan Kebudayaan RI Nomor 62/E/KPT/2020 (Ristekdikti, 2017).

Berbagai penelitian mengenai tingkat pengembalian investasi pendidikan telah banyak dilakukan. Pengembalian investasi ke perguruan tinggi secara signifikan dan positif meningkatkan penghasilan pekerja (Hadia et al., 2019). Semakin tinggi pendidikan maka pengembalian investasi pendidikan akan semakin besar (Purnastuti et al., 2013). Penelitian yang lain menghasilkan hasil yang berbeda, Suga (2017) menemukan bahwa gelar sarjana dan pilihan universitas hanya sedikit mempengaruhi upah. Studi yang dilakukan Paweenawat \& Vechbanyongratana (2015) menemukan bahwa lulusan STEM yang bekerja di bidang STEM mendapatkan pendapatan lebih tinggi jika dibandingkan bekerja di bidang non STEM. Pada perguruan tinggi, jurusan teknik menghasilkan tingkat pengembalian investasi pendidikan paling tinggi daripada jurusan lain (Black et al., 2003). Berdasarkan gender, studi oleh Lewis et al. (2004) memperoleh bahwa tingkat pengembalian investasi pendidikan lebih tinggi laki-laki daripada perempuan; namun hasil yang berbeda diperoleh Hendajany et al. (2016) dimana tingkat pengembalian investasi pendidikan lebih tinggi pada perempuan daripada pada laki-laki.

Berdasarkan tinjauan literatur dan studi empiris penelitian sebelumnya, dua hipotesis dibangun untuk diajukan dalam penelitian ini:

H1: Tingkat pengembalian investasi pendidikan tinggi lulusan S3 program studi STEM lebih tinggi daripada lulusan program studi STEM di tingkat pendidikan lainnya. 
H2: Tingkat pengembalian investasi pendidikan tinggi pekerja lulusan program studi STEM laki-laki lebih tinggi daripada perempuan.

Berdasarkan pengembangan hipotesis yang telah dikemukakan, rancangan kerangka pemikiran yang menunjukkan hubungan antar variabel yang dianalisis dapat digambarkan pada Gambar 5.

\section{METODE PENELITIAN}

Penelitian ini menggunakan data SAKERNAS Agustus 2019 dari Badan Pusat Statistik (BPS). SAKERNAS merupakan survei berbasis rumah tangga yang bertujuan memperoleh data pokok ketenagakerjaan yang berkesinambungan yang dilakukan dua periode dalam satu tahun, yaitu pada bulan Februari 2019 dan Agustus 2019 (BPS, 2019). Unit analisis dalam penelitian ini adalah angkatan kerja yang berusia 15 tahun ke atas dengan pendidikan tertinggi minimal D1 jurusan program studi STEM.

Model persamaan pendapatan mengacu model pendapatan Mincer pada persamaan (1) dimana variabel $S$ dinyatakan dalam jumlah tahun bersekolah sehingga $\beta_{1}$ dapat langsung diinterpretasikan sebagai tingkat pengembalian investasi pendidikan. Namun dalam pengembangannya, variabel $\mathrm{S}$ dapat dimodifikasi menjadi variabel dummy jenjang pendidikan agar mudah untuk mengestimasi tingkat pengembalian investasi pendidikan untuk tiap jenjang pendidikan (El-Hamidi, 2006). Untuk persamaan penghasilan yang menggunakan dummy jenjang pendidikan, koefisien tidak bisa langsung diintepretasikan sebagai tingkat pengembalian investasi pendidikan. Nilai tingkat pengembalian itu merujuk pada studi El-Hamidi (2006) dan Purnastuti et al. (2013) yaitu:

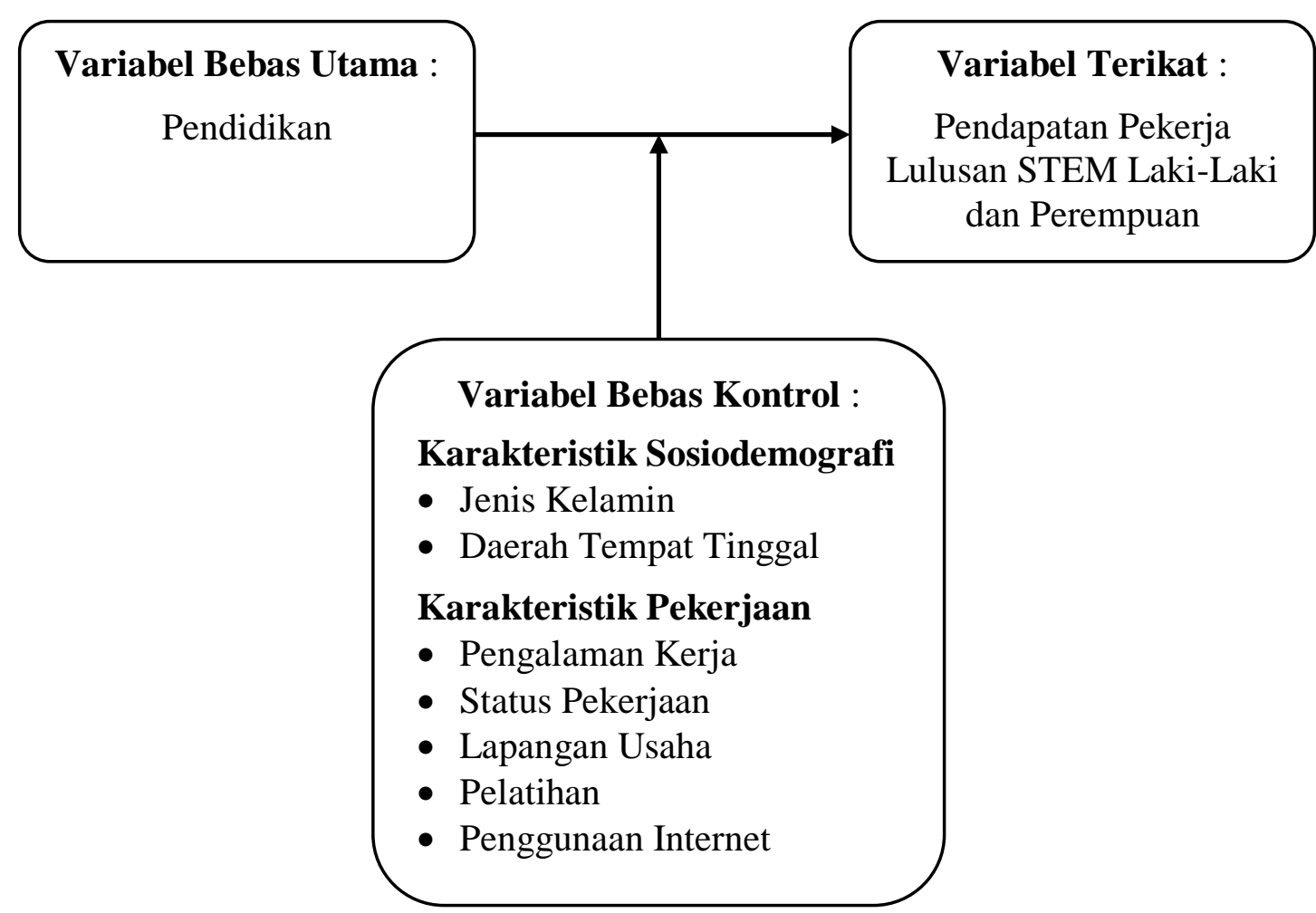

\section{Gambar 3. Kerangka Pemikiran}

Sumber: Diolah penulis, 2021. 


$$
r_{k}=\frac{\beta_{k}-\beta_{k-1}}{\Delta n_{k}}
$$

dimana $\beta_{k}$ adalah koefisien pada jenjang $k$, $\beta_{k-1}$ adalah koefisien pada jenjang $k-1$ sedangkan $\Delta \mathrm{n}_{\mathrm{k}}$ adalah perbedaan jumlah tahun bersekolah pada tingkat pendidikan ke $k$ dan $(k-1)$.

Mengestimasi nilai koefisien dari fungsi pendapatan Mincer menggunakan metode OLS secara langsung akan menyebabkan masalah yang disebut self-selection bias. Bias terjadi karena sampel yang digunakan untuk mengestimasi fungsi pendapatan Mincer adalah individu yang pada saat dilakukan survei berpartispasi dalam pasar kerja dan memperoleh upah atau pendapatan, sedangkan bagi individu yang tidak memiliki informasi pendapatan dan pekerja yang tidak dibayar tidak dilibatkan (Mardiana, 2014).

Untuk mengatasi persoalan selectivity bias tersebut maka metode analisis yang digunakan adalah metode dua tahap Heckman (Two step Heckman method). Sebelum melakukan estimasi fungsi pendapatan Mincer, maka yang dilakukan terlebih dahulu adalah menghitung probabilitas bekerja pada pekerja dengan menggunakan karakteristik tertentu dari pekerja (Heckman, 1979). Langkah pertama yaitu dengan mengestimasi probabilitas partisipasi bekerja dengan menggunakan model probit. Dari analisis tahap pertama ini akan diestimasi besarnya variabel lamda $(\lambda)$ yang biasa disebut inverse mills ratio. Langkah kedua yaitu memasukkan variabel $\lambda$ itu ke dalam fungsi Mincer sebagai salah satu variabel bebas. Model partisipasi bekerja dalam penelitian ini adalah:

$$
\begin{aligned}
\mathrm{Zi}= & \beta_{0}+\beta_{1} \mathrm{JK}+\beta_{2} \text { Tinggal }+\beta_{3} U \text { Umur }+\beta_{4} \mathrm{Umur}^{2} \\
& +\beta_{5} \text { Stat } \_ \text {Kawin }+\beta_{6} \text { Keb_Balita } \ldots \ldots \ldots \ldots . . .
\end{aligned}
$$

Variabel $Z i$ berbentuk katagori yang menjelaskan partisipasi bekerja dimana bernilai 1 jika bekerja dan mendapatkan pendapatan dan bernilai 0 jika bekerja tidak mendapatkan pendapatan atau tidak bekerja; dan, $\beta$ yaitu koefisien determinan partisipasi bekerja yang melibatkan aspek karakteristik pekerja seperti umur, jenis kelamin, status kawin, tempat tinggal dan keberadaan balita.

Fungsi pendapatan pekerja lulusan Program Studi STEM (dummy Pendidikan) adalah:

Ln Pendapatan STEM $=\beta_{0}+\beta_{1} \mathrm{D} 3+\beta_{2} \mathrm{D} 4 \mathrm{~S} 1$

$$
+\beta_{3} \mathrm{~S} 2+\beta_{4} \mathrm{~S} 3+\sum_{\mathrm{i}}^{n} \beta_{\mathrm{i}} X_{\mathrm{j}}+\lambda \mathrm{i}+\varepsilon \mathrm{i}
$$

Fungsi pendapatan pekerja lulusan Program Studi STEM (Lama Sekolah) adalah:

Ln Pendapatan STEM $=\beta_{0}+\beta_{1}$ Lama Sekolah $+\sum_{i}^{n} \beta_{\mathrm{i}} X_{\mathrm{j}}+\lambda \mathrm{i}+\varepsilon \mathrm{i}$

dimana variabel bebas utama D3, D4S1, S2, S3 adalah variabel dummy dari pendidikan dan lama sekolah; $X_{\mathrm{jj}}$ adalah variabel kontrol yaitu pengalaman, status pekerjaan, lapangan usaha, pelatihan, penggunaan internet, jenis kelamin, dan daerah tempat tinggal; $\lambda \mathrm{ij}$ adalah inverse mills ratio.

\section{HASIL ANALISIS}

Berdasarkan hasil dari pengolahan data diperoleh sampel untuk model partisipasi bekerja sebanyak 532.213 individu, dan sampel untuk model fungsi pendapatan pekerja lulusan program studi STEM adalah sebanyak 17.467 individu dengan perincian jumlah pekerja laki-laki sebanyak 8.602 individu dan pekerja perempuan sebanyak 8.865 individu.

Pekerja lulusan program studi STEM didominasi pekerja berjenjang pendidikan DIV/S1 yaitu sebesar 54,60 persen. Gambar 4 memperlihatkan bahwa sampel pada pekerja lulusan program studi STEM baik perempuan maupun laki-laki didominasi oleh pekerja dengan lulusan program studi STEM pada jenjang pendidikan D3 dan DIV/S1. Pada 
pekerja laki-laki sebagian besar jenjang pendidikannya yaitu DIV/S1; sedangkan pada perempuan berimbang antara D3 dan DIV/S1.

Tabel 1 memperlihatkan bahwa pekerja lulusan program studi STEM di Indonesia mayoritas memiliki lama pengalaman kerja potensial 0-19 tahun, status pekerjaan formal, bekerja pada sektor jasa, tidak pernah mengikuti pelatihan, dan internet digunakan sebagai penunjang dalam bekerja.

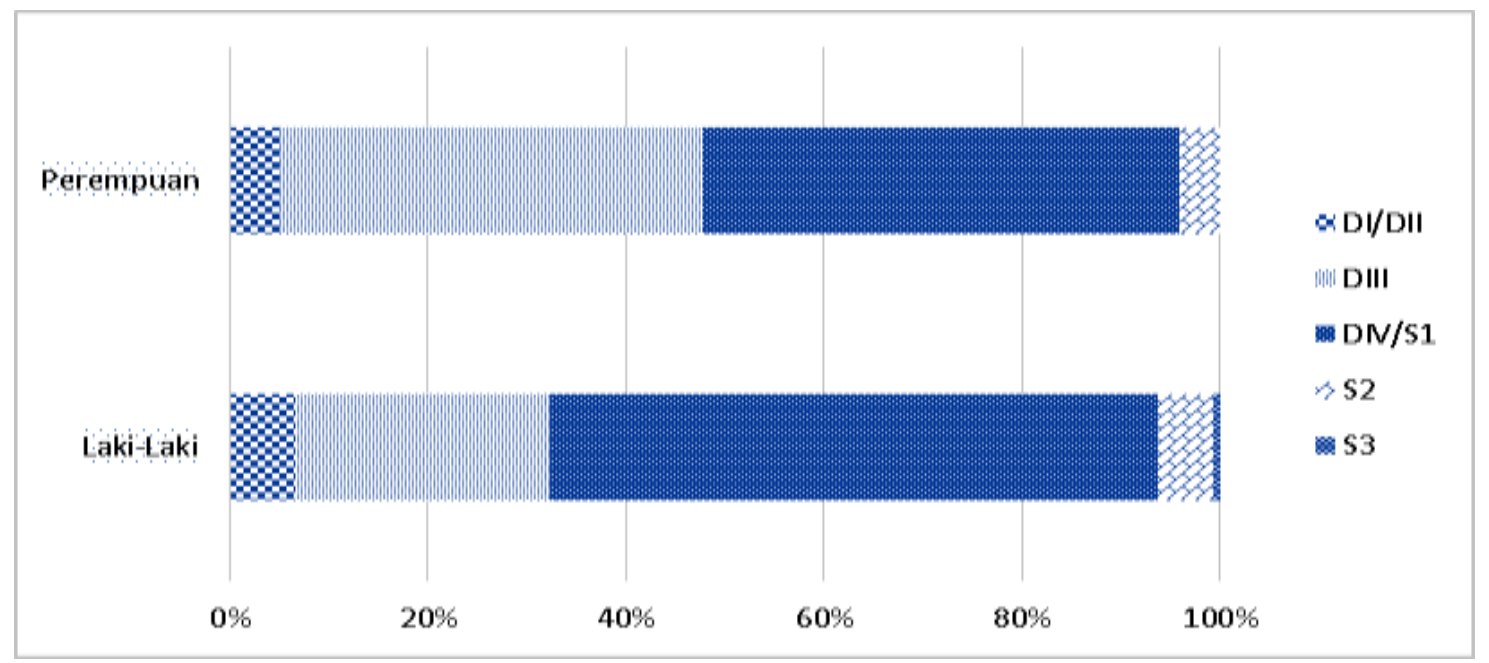

Gambar 4. Pekerja Lulusan Program Studi STEM berdasarkan Jenjang Pendidikan Sumber: Data sekunder diolah, 2021.

Tabel 1. Karakteristik Pekerja Lulusan STEM menurut Variabel Utama

\begin{tabular}{|c|c|c|}
\hline Karakteristik & Pekerja Laki-laki (\%) & Pekerja Perempuan (\%) \\
\hline Pengalaman Kerja (tahun) & 35,05 & 47,29 \\
\hline $0-9$ & 31,53 & 32,68 \\
\hline $10-19$ & 21,86 & 14,77 \\
\hline $20-29$ & 10,15 & 4,86 \\
\hline $30-39$ & 1,42 & 0,41 \\
\hline \multicolumn{3}{|l|}{$40+$} \\
\hline Status Pekerjaan & 88,14 & 93,71 \\
\hline Formal & 11,86 & 6,29 \\
\hline \multicolumn{3}{|l|}{ Informal } \\
\hline \multicolumn{3}{|l|}{ Lapangan Usaha } \\
\hline Pertanian & 3,31 & 0,52 \\
\hline Industri & 17,77 & 4,17 \\
\hline Jasa & 78,90 & 95,31 \\
\hline \multicolumn{3}{|l|}{ Pengalaman Pelatihan } \\
\hline Pernah Mengikuti & 39,46 & 42,09 \\
\hline Tidak Pernah Mengikuti & 60,54 & 57,91 \\
\hline \multicolumn{3}{|l|}{ Penggunaan Internet } \\
\hline Menggunakan & 78,14 & 74,34 \\
\hline Tidak Menggunakan & 21,86 & 25,66 \\
\hline Total & 100,00 & 100,00 \\
\hline
\end{tabular}

Sumber: Data sekunder diolah, 2021. 


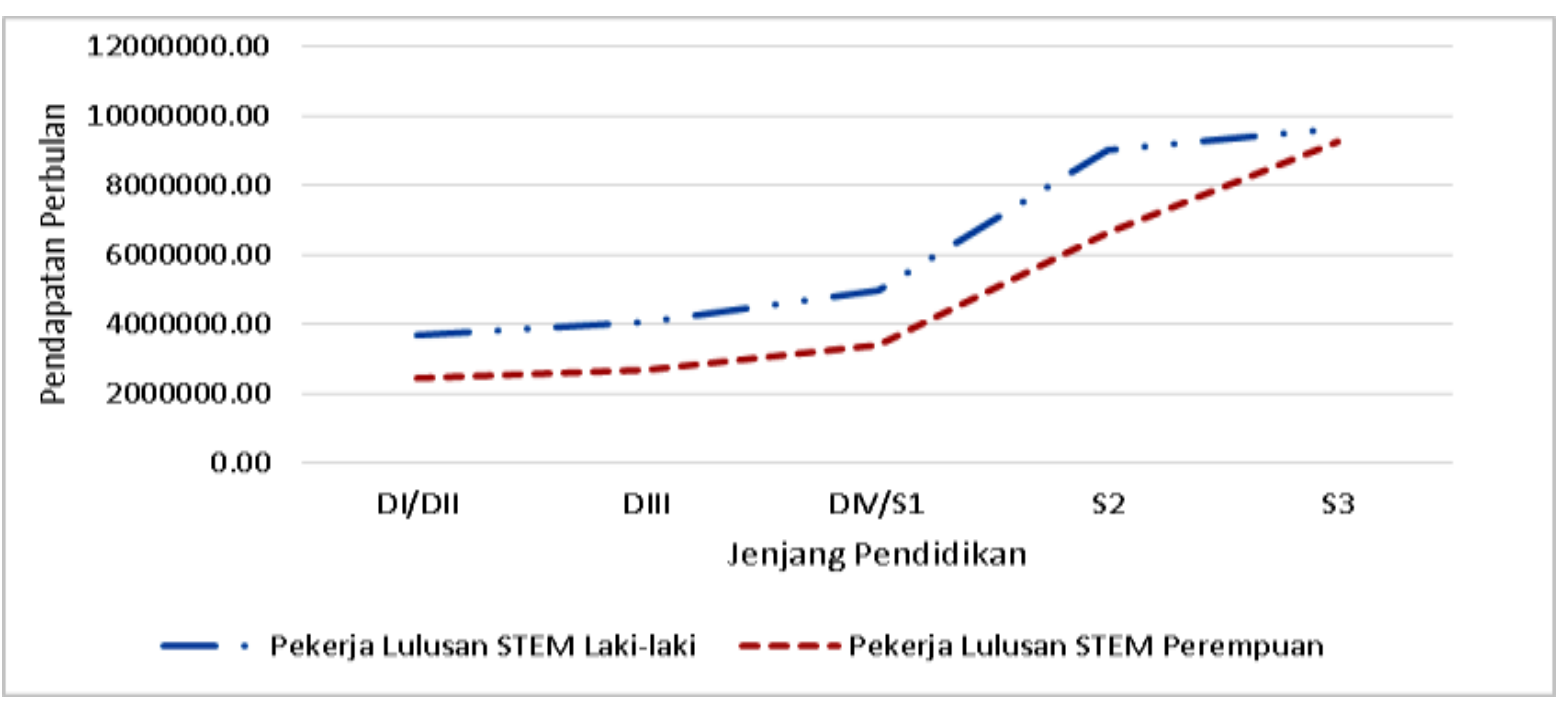

\section{Gambar 5. Pendapatan Lulusan STEM berdasarkan Jenis Kelamin dan Jenjang Pendidikan}

Sumber: Data sekunder diolah, 2021.

Tabel 1 juga mengidentifikasi berdasarkan jenis kelaminnya, sebelum dikontrol oleh pengaruh variabel lain, dimana diperoleh nilai Unadjusted Odds Ratio (UOR) sebagai berikut. Pertama, pekerja perempuan lulusan program studi STEM cenderung dua kali lebih tinggi bekerja pada sektor pekerjaan formal dibandingkan dengan pekerja laki-laki lulusan program studi STEM.

Kedua, kaum pekerja laki-laki lulusan program studi STEM cenderung bekerja pada sektor pertanian dan industri, yaitu pada lapangan usaha pertanian sebesar 6,57 kali, dan pada lapangan usaha industri sebesar 4,96 kali lebih tinggi daripada pekerja perempuan lulusan program studi STEM. Namun untuk lapangan usaha jasa, pekerja perempuan lulusan program studi STEM adalah 5,43 kali lebih tinggi bekerja di sektor itu dibandingkan dengan pekerja laki-laki lulusan STEM.

Ketiga, pekerja perempuan lulusan program studi STEM cenderung sebesar 1,12 kali lebih tinggi dalam memiliki pengalaman pelatihan daripada pekerja laki-laki lulusan program studi STEM. Terakhir, pekerja lakilaki lulusan program studi STEM cenderung 1,23 kali lebih menggunakan internet untuk menunjang pekerjaan dibandingkan pekerja perempuan lulusan program studi STEM.
Berdasarkan Gambar 5 terlihat bahwa semakin tinggi tingkat pendidikan yang ditamatkan oleh pekerja lulusan program studi STEM, maka jumlah pendendapatan yang diterima semakin besar. Pada semua jenjang pendidikan, pendapatan pekerja laki-laki lebih timggi daripada jumlah pendapatan pekerja perempuan. Selisih pendapatan antara pekerja laki-laki dengan perempuan lulusan program studi STEM tertinggi terjadi pada jenjang S2 yaitu sebesar Rp. 2.370.000,-; sedangkan selisih nilai terendah terjadi pada jenjang pendidikan S3 yaitu sebesar Rp. 357.000,--

Hasil estimasi atas model pendapatan pekerja lulusan program studi STEM terangkum dalam Tabel 2 dimana kolom 2 menyatakan model secara keseluruhan serta kolom 3 dan 4 adalah model yang telah dipisahkan antara sampel pekerja lulusan program studi STEM yang berjenis kelamin laki-laki dan perempuan. Hasil estimasi memperlihatkan bahwa hampir semua variabel bebas memiliki pengaruh signifikan terhadap pendapatan, kecuali variabel lapangan usaha pada sektor jasa dan variabel tempat tinggal pada pekerja laki-laki lulusan program studi STEM dimana hasilnya menyatakan tidak signifikan. 
Tabel 2. Hasil Estimasi Model Fungsi Pendapatan Pekerja Lulusan STEM

\begin{tabular}{|c|c|c|c|}
\hline \multirow{2}{*}{ Variabel } & \multicolumn{3}{|c|}{ Koefisien (Standard Error) } \\
\hline & Laki-Laki + Perempuan & Laki-Laki & Perempuan \\
\hline Tingkat Pendidikan & \multicolumn{3}{|c|}{ Variabel Acuan: D1 / D2 } \\
\hline D3 & $\begin{array}{c}0,1691 \\
(0,0258) * * *\end{array}$ & & \\
\hline $\mathrm{D} 4 / \mathrm{S} 1$ & $\begin{array}{c}0,2639 \\
(0,0251)^{* * *}\end{array}$ & & \\
\hline $\mathrm{S} 2$ & $\begin{array}{c}0,7012 \\
(0,0359)^{* * *}\end{array}$ & & \\
\hline S3 & $\begin{array}{c}0,8244 \\
(0,0922)^{* * *}\end{array}$ & & \\
\hline Lama Sekolah & & $\begin{array}{c}0,1414 \\
(0,0876)^{* * *}\end{array}$ & $\begin{array}{c}0,1502 \\
(0.0105)^{* * *}\end{array}$ \\
\hline Pengalaman Kerja & $\begin{array}{c}0,0593 \\
(0,0037)^{* * *}\end{array}$ & $\begin{array}{c}0,0465 \\
(0,0055)^{* * *}\end{array}$ & $\begin{array}{c}0.0693 \\
(0,0060)^{* * *}\end{array}$ \\
\hline Pengalaman Kerja Kuadrat & $\begin{array}{c}-0,0008 \\
(0,0001) * * *\end{array}$ & $\begin{array}{c}-0,0005 \\
(0,0002) * * *\end{array}$ & $\begin{array}{c}-0,0009 \\
(0,0002)^{* * *}\end{array}$ \\
\hline Status Kerja & \multicolumn{3}{|c|}{ Variabel Acuan: Sektor Informal } \\
\hline Formal & $\begin{array}{c}0,3510 \\
(0,0210)^{* * *}\end{array}$ & $\begin{array}{c}0,2619 \\
(0,0256)^{* * *}\end{array}$ & $\begin{array}{c}0,4793 \\
(0,3553)^{* * *}\end{array}$ \\
\hline Lapangan Usaha & \multicolumn{3}{|c|}{ Variabel Acuan: Sektor Pertanian } \\
\hline Industri & $\begin{array}{c}0,3605 \\
(0,0468)^{* * *}\end{array}$ & $\begin{array}{c}0,4071 \\
(0,0494)^{* * *}\end{array}$ & $\begin{array}{c}0,2754 \\
(0,1243)^{* *}\end{array}$ \\
\hline Jasa & $\begin{array}{l}-0,0693 \\
(0,0440)\end{array}$ & $\begin{array}{l}-0,0466 \\
(0,0462) \\
\end{array}$ & $\begin{array}{l}-0,0886 \\
(0,1177) \\
\end{array}$ \\
\hline Pelatihan Kerja & \multicolumn{3}{|c|}{ Variabel Acuan: Tidak Pernah } \\
\hline Pernah & $\begin{array}{c}0,1403 \\
(0,1201)^{* * *}\end{array}$ & $\begin{array}{c}0,1136 \\
(0,0164)^{* * *}\end{array}$ & $\begin{array}{c}0,1697 \\
(0,0174)^{* * *}\end{array}$ \\
\hline
\end{tabular}

\begin{tabular}{|c|c|c|c|}
\hline Penggunaan Internet & \multicolumn{3}{|c|}{ Variabel Acuan: Tidak Menggunakan Internet } \\
\hline Menggunakan internet & $\begin{array}{c}0,2687 \\
(0,0140)^{* * *}\end{array}$ & $\begin{array}{c}0,3279 \\
(0,0199) * * *\end{array}$ & $\begin{array}{c}0,2208 \\
(0,0197)^{* * *}\end{array}$ \\
\hline Tempat Tinggal & \multicolumn{3}{|c|}{ Variabel Acuan: Perdesaan } \\
\hline Perkotaan & $\begin{array}{c}0,1609 \\
(0,0766)^{* *}\end{array}$ & $\begin{array}{c}0,0193 \\
(0,1171)\end{array}$ & $\begin{array}{c}0,3140 \\
(0,1226)^{* * *}\end{array}$ \\
\hline Jenis Kelamin & \multicolumn{3}{|c|}{ Variabel Acuan: Perempuan } \\
\hline Laki-laki & $\begin{array}{c}0,1168 \\
(0,0438)^{* * *}\end{array}$ & & \\
\hline Lamda & $\begin{array}{c}-0,7040 \\
(0,2719)^{* * *}\end{array}$ & $\begin{array}{c}-1,2095 \\
(0,4497)^{* * *}\end{array}$ & $\begin{array}{l}-0,2098 \\
(0,4104)\end{array}$ \\
\hline Konstanta & $\begin{array}{c}13,6521 \\
(0,2375)^{* * *}\end{array}$ & $\begin{array}{c}12,2443 \\
(0.3239)^{* * *}\end{array}$ & $\begin{array}{c}10,9749 \\
(0,4079)^{* * *}\end{array}$ \\
\hline Observations & 17.467 & 8.602 & 8.865 \\
\hline $\mathrm{F}$ & 631,91 & 377,9 & 373,93 \\
\hline Prob $>F$ & 0,0000 & 0,0000 & 0,0000 \\
\hline R-square & 0,3364 & 0,3055 & 0,2969 \\
\hline Root MSE & 0,7598 & 0,72424 & 0,79051 \\
\hline
\end{tabular}

Catatan: ** Signifikan pada taraf 5\%,*** Signifikan pada taraf $1 \%$, angka dalam tanda ( ) merupakan nilai standar error.

Sumber: Data sekunder diolah, 2021. 
Secara keseluruhan pada kelompok sampel perempuan, nilai lambda $(\lambda)$ bernilai signifikan yang berarti bahwa dalam data terdapat selectivity bias; sedangkan nilai lambda $(\lambda)$ pada sampel laki-laki bernilai tidak signifikan. Hasil pengujian signifikansi model fungsi pendapatan diperoleh nilai Prob. F sebesar 0,000 atau lebih kecil dari 0,05 yang mengindikasikan bahwa semua variabel bebas memengaruhi variabel terikat pada tingkat signifikansi 1 persen dan model yang dibangun adalah layak untuk dianalisis lebih lanjut.

Hasil estimasi tingkat pengembalian investasi pendidikan lulusan program studi STEM berdasarkan tingkat pendidikan menunjukkan hasil bervariasi. Pada pekerja lulusan program studi STEM, jenjang D3 mempunyai tingkat pengembalian investasi pendidikan sebesar 5,64 persen; pada level D4/S1 diperoleh sebesar 2,3 persen; pada level S2 sebesar 21,86 persen; dan, pada level S3 sebesar 4,10 persen. Sementara itu, tingkat pengembalian investasi pendidikan pekerja perempuan lulusan program studi STEM adalah sebesar 15,02 persen; dimana tingkat pengembalian ini lebih tinggi daripada yang dicapai pekerja laki-laki sebesar 14,14 persen.

\section{Pembahasan}

Pada model secara keseluruhan, terdapat empat dummy tingkat pendidikan. Seluruh koefisien variabel dummy pendidikan bernilai positif dan makin meningkat seiring dengan meningkatnya tingkat pendidikan. Pekerja lulusan program studi STEM dengan tingkat pendidikan D3 mendapatkan peningkatan pendapatan terendah, sedangkan tingkat pendidikan S3 mendapatkan peningkatan pendapatan tertinggi. Hal ini sesuai dengan hasil analisis deskriptif sebelumnya dan menggambarkan bahwa pendidikan masih menjadi tolok ukur produktivitas pekerja. Keadaan ini sering disebut sheepskin effect, yaitu pendapatan akan cenderung naik dengan peningkatan jenjang pendidikan yang ditamatkan dibuktikan dengan sertifikat pendidikan yang dimiliki (Hendajany et al., 2016; Amalia \& Sugiharti, 2020).

Pada Tabel 2 terlihat bahwa tingkat pengembalian investasi pendidikan tertinggi terjadi pada pekerja lulusan program studi STEM untuk jenjang S2, dan terendah untuk jenjang D4/S1. Hal ini tidak sesuai dengan hipotesis yang diajukan dalam penelitian ini, serta juga tidak sesuai dengan hasil empiris yang diperoleh Amalia \& Sugiharti (2020) dimana semakin tinggi pendidikan maka akan menghasilkan tingkat pengembalian investasi pendidikan yang semakin tinggi.

Tujuan program pendidikan diploma adalah mencetak lulusan yang diharapkan telah siap bekerja. Yang menarik dalam penelitian ini adalah adanya bukti empiris bahwa keputusan memilih untuk melanjutkan pendidikan STEM hingga jenjang pendidikan D4/S1 menghasilkan tingkat pengembalian investasi pendidikan sebesar 2,3 persen yang mana tidak jauh berbeda dengan pekerja yang memiliki pendidikan hingga jenjang D3. Hal ini bisa terjadi karena adanya penilaian di dalam pasar tenaga kerja bahwa kemampuan lulusan program studi STEM untuk jenjang pendidikan D3 ataupun D4/S1 dipandang memiliki kualifikasi yang hampir sama dan telah siap untuk bekerja, sehingga pendapatan yang dihasilkan tidak jauh berbeda.

Tingkat pengembalian investasi pendidikan program studi STEM tertinggi terjadi ketika seseorang melanjutkan pendidikan hingga S2. Terlihat tingkat pengembalian investasi pendidikan program studi STEM pada tingkat pendidikan S2 sebesar 21,86 persen. Pada dunia kerja, seringkali untuk mendapatkan pekerjaan yang lebih baik dan untuk promosi jabatan disyaratkan untuk memiliki tingkat pendidikan hingga jenjang pascasarjana. Jumlah lulusan pascasarjana 
tentunya tidak sebanyak jenjang pendidikan dibawahnya, sehingga memilih melanjutkan pendidikan program studi STEM pada jenjang pascasarjana masih sangat menguntungkan bagi angkatan kerja di Indonesia.

Tingkat pengembalian investasi pendidikan pada program studi STEM untuk jenjang pendidikan S3 sebesar 4,10 persen tidak sebesar pada tingkat pendidikan S2. Hal ini sesuai dengan temuan empiris dari penelitian yang dilakukan oleh Suga (2017) bahwa memperoleh gelar pascasarjana lebih ditujukan untuk orientasi non-uang seperti memperoleh penempatan kerja yang lebih sesuai dengan tipe keahlian dan background pendidikan yang dimiliki.

Program studi STEM sering dianggap sebagai program studi bagi kaum laki-laki, sehingga untuk beberapa program studi STEM seperti teknik, terjadi situasi bahwa sebagian besar mahasiswanya adalah lakilaki. Dalam penelitian ini diperoleh tingkat pengembalian investasi pendidikan lulusan STEM perempuan sebesar 15,02 persen yang mana lebih tinggi daripada kaum laki-laki yang hanya sebesar 14,14 persen. Hasil penelitian ini karenanya sesuai dengan temuan empiris milik Hendajany et al. (2016) dimana tingkat pegembalian investasi pendidikan lebih besar pada perempuan daripada laki-laki. Melanjutkan pendidikan kepada program studi STEM untuk kaum perempuan nyatanya memberikan manfaat lebih tinggi saat memasuki pasar kerja dibandingkan yang diperoleh kaum laki-laki.

Mahalnya biaya pendidikan terutama pada program studi STEM menjadikan beasiswa menjadi salah satu cara untuk menarik minat masyarakat untuk melanjutkan sekolah program studi tersebut. Penambahan jumlah beasiswa terutama pada program studi STEM pada jenjang pendidikan pascasarjana mungkin perlu dilakukan mengingat tingkat pengembalian investasi pendidikan pada jenjang tersebut tergolong tinggi.

Peraturan pemerintah yang mendorong peningkatan pendirian program studi di bidang STEM dinilai telah tepat untuk mencukupi kebutuhan tenaga kerja dengan skill yang dibutuhkan sesuai perkembangan zaman. Namun demikian, pemerataan fasilitas pendidikan dan kualitas pendidikan perlu menjadi perhatian sehingga pembangunan pendidikan tinggi terutama yang berbasis STEM bisa merata di seluruh Indonesia.

Pemberian kesempatan yang sama pada laki-laki dan perempuan untuk bersekolah dan memiliki pekerjaan di bidang STEM diharapkan tidak hanya menjadi tanggung jawab pemerintah tetapi juga masyarakat pada umumnya. Stereotipe mengenai program studi STEM yang syarat akan maskulinitas harus dihilangkan karena tingkat pengembalian investasi pendidikan program studi STEM pada perempuan nyatanya lebih tinggi dibandingkan dengan laki-laki.

\section{SIMPULAN}

Melanjutkan pendidikan tinggi pada program studi STEM secara positif dapat meningkatkan pendapatan pekerja. Walaupun biaya pendidikan pada program studi STEM terkenal lebih mahal ketimbang non-STEM, namun melanjutkan pendidikan pada program studi STEM dapat menghasilkan tingkat pengembalian investasi pendidikan yang menguntungkan bagi pekerja terutama yang memiliki tingkat pendidikan pascasarjana.

Beberapa program studi STEM yang dianggap sebagai program studi yang syarat dengan sisi maskulinitas dan adanya isu diskriminasi terhadap perempuan terutama saat lulusan program studi STEM memasuki dunia kerja pada sektor STEM, sehingga menyebabkan minimnya jumlah perempuan yang mengambil pendidikan dengan jurusan STEM. Isu diskriminasi juga terlihat pada 
pendapatan yang diterima pekerja perempuan lulusan program studi STEM lebih rendah daripada pendapatan pekerja laki-laki lulusan program studi STEM pada semua tingkat pendidikan. Namun demikian, nilai tingkat pengembalian investasi pendidikan pada pekerja perempuan lulusan program studi STEM ternyata lebih tinggi daripada pekerja laki-laki lulusan program studi STEM. Pilihan untuk melanjutkan pendidikan pada program studi STEM bagi kaum perempuan juga menghasilkan nilai pengembalian investasi pendidikan yang tidak kalah dengan laki-laki.

Penambahan program beasiswa bagi mahasiswa terutama program studi STEM, peraturan pemerintah yang lebih mendorong peningkatan pendirian program studi STEM, dan pemberian kesempatan yang sama antara laki-laki dan perempuan dalam memperoleh pendidikan dan pekerjaan di bidang STEM, merupakan beberapa rekomendasi kebijakan yang diharapkan meningkatkan minat dan jumlah fasilitas pendidikan di bidang STEM.

Keputusan melanjutkan pendidikan pada bidang STEM dipengaruhi beberapa faktor selain faktor demografis, seperti kemampuan kognitif diri sendiri dan orang tua. Kelemahan pada penelitian ini adalah tidak tersedianya data mengenai kemampuan kognitif tersebut sehingga selectivity bias mungkin masih terjadi akibat proses estimasi tidak dilakukan pada probabilitas bersekolah di program studi STEM. Selain itu, terdapat 2,22 persen data terisi program studi yang ditamatkan adalah opsi "lainnya" sehingga tidak dimasukkan dalam sampel STEM. Kesalahan cakupan mungkin bisa terjadi karena sampel yang harusnya masuk dalam kategori STEM tetapi tidak dimasukkan karena kurangnya informasi.

\section{REFERENSI}

Amalia, N., \& Sugiharti, L. (2020). Perkembangan tingkat pengembalian investasi pendidikan menengah di Indonesia tahun 2015 dan 2018. Jurnal Ekonomi Dan Pembangunan Indonesia, 20(2), 231-252. doi: 10.21002/jepi. v20i2.1310.

Beller, A. H. (1982). Occupational segregation by sex: Determinants and changes. The Journal of Human Resources, 17(3), 371-392. doi: 10.2307/145586.

Black, D. A., Sanders, S., \& Taylor, L. (2003). The economic reward for studying economics. Economic Inquiry, 41(3), 365-377. doi: 10.1093/ei/ cbg014.

Borjas, G. J. (2016). Labor economics (Seventh ed.). McGraw-Hill Education.

BPS. (2019). Keadaan angkatan kerja di Indonesia Agustus 2019. Retrieved from https://www.bps.go.id/ publication/2019/11/29/96138ece33ccc 220007acbdd/keadaan-angkatan-kerjadi-indonesia-agustus-2019.html.

Crisp, G., Nora, A., \& Taggart, A. (2009). Student characteristics, pre-college, college, and environmental factors as predictors of majoring in and earning a STEM degree: An analysis of students attending a hispanic serving institution. American Educational Research Journal, 46(4), 924-942. doi: 10.3102/ 0002831209349460.

Daly, A., Lewis, P., Corliss, M., \& Heaslip, T. (2015). The private rate of return to a university degree in Australia. Australian Journal of Education, 59(1), 92-112. doi: 10.1177/000494411456 5117.

Department of Homeland Security. (2016). STEM designated degree program list. 2(9). Retrieved from https://www.ice. gov/sites/default/files/documents/Docu ment/2016/stem-list.pdf.

El-Hamidi, F. (2006). General or vocational schooling? Evidence on school choice, returns, and "sheepskin" effects from Egypt 1998. The Journal of Policy Reform, 9(2), 157-176. doi: 10.1080/ 13841280600772861 . 
Firman, H. (2016). Pendidikan STEM: Apa, mengapa, bagaimana? Universitas Pendidikan Indonesia, (November), 19. Retrieved from https://www. academia.edu/38895738/pendidikan_ste m_apa_mengapa_dan_bagaimana.

Gonzales, H. B., \& Kuenzi, J. J. (2014). Science, technology, engineering and mathematics (STEM) education: A primer. Journal of Education and Learning (EduLearn), 7(2), 246-258. Retrieved from https://www.911.gov/ pdf/CRS_Report_Emergency_Commun ications_Future_of_911_2010.pdf.

Hadia, D., Bachtiar, N., \& Elfindri, E. (2019). Human capital investment: An analysis of the return of higher education. Jurnal Perspektif Pembiayaan Dan Pembangunan Daerah, 7(1), 49-62. doi: 10.22437/ppd.v7i1.6965.

Hadiat. (2020). Rancangan teknokratik RPJMN 2020-2024 bidang pendidikan tinggi dan iptek sistematika pemaparan. (September 2019). Retrieved from http://fe.unj.ac.id/wp-content/uploads/ 2019/09/Paparan-Ranc.Tekn-RPJMN2020-2024-bidang-PT-dan-Iptek-02.pdf

Heckman, J. J. (1979). Sample selection bias as a specification error. Econometrica, 47(1), 153-161. doi: 10.2307/1912352.

Hendajany, N., Widodo, T., \& Sulistyaningrum, E. (2016). Perkembangan tingkat pengembalian investasi pendidikan antar-provinsi: Indonesia family life survey 1993-2014. Jurnal Ekonomi Dan Pembangunan Indonesia, 17(1), 44-57. doi: 10.21002/jepi. v17i1.647.

ILO. (2017). Women in STEM workforce readiness and development programme in Indonesia. 1-6. Retrieved from https://www.ilo.org/jakarta/whatwedo/p rojects/WCMS_624553/lang-en/index.htm.

Kemenristekdikti. (2019). Statistik pendidikan tinggi (Higher education statistics) 2019. In Pusdatin Kemenristekdikti. Retrieved from http://www.mohe.gov. my/web_statistik/.
Khairani, Mukhni, \& Aini, F. Q. (2018). Pembelajaran berbasis STEM dalam perkuliahan kalkulus di perguruan tnggi. UJMWS (Uninus Journal of Mathematics Education and Science), 3(2), 104-111. Retrieved from http://103.66.199.204/index.php/UJME S/article/view/544.

Kharas, H., \& Kohli, H. (2011). What is the middle income trap, why do countries fall into it, and how can it be avoided? Global Journal of Emerging Market Economies, 3(3), 281-289. doi: 10.1177/097491011100300302.

Lee, M. H., Chai, C. S., \& Hong, H. Y. (2019). STEM education in Asia Pacific: Challenges and development. Asia-Pacific Education Researcher, 28(1), 1-4. doi: 10.1007/s40299-0180424-z.

Lewis, P., Daly, A., \& Fleming, D. (2004). Why study economics? The private rate of return to an economics degree. Economic Papers, 23(3), 234-243. doi: 10.1111/j.1759-3441.2004.tb00368.x.

LIPI. (2018). Gender dalam ilmu pengetahuan dan teknologi: Perkembangan, kebijakan, \& tantangannya di Indonesia (W. Hermawati, Ed.). Retrieved from http://penerbit.lipi.go. $\mathrm{id} /$ data/naskah1521570363.pdf.

Mardiana. (2014). Kesenjangan penghasilan antar gender para wirausaha dan pekerja tahun 2013. Tesis. Program Pascasarjana Multidisiplin Kajian Kependudukan dan Ketenagakerjaan, Universitas Indonesia.

Mincer, J. (1974). The human capital earnings function. Schooling, Experience, and Earnings, I, 83-96. Retrieved from https://www.nber.org/system/files/chapt ers/c1767/c1767.pdf.

Nelson, G. R. (2008). Differential tuition by undergraduate major: Its use, amount, and impact at public research universities. Dissertation Abstracts International Section A: Humanities and Social Sciences, 69(2-A), 513. Retrieved from http://search.ebscohost. 
com/login.aspx ?direct=true \&AuthType $=\mathrm{ip}$, shib\&db=psyh\&AN=2008-99151$091 \&$ site $=$ ehost-live $\&$ custid $=$ = 4121186 .

Nurteta, S. (2016). Perkembangan tingkat pengembalian investasi pendidikan tinggi di Indonesia (Analisis data SAKERTI tahun 2000, 2007, dan 2014). Tesis. Program Pascasarjana Multidisiplin Kajian Kependudukan dan Ketenagakerjaan, Universitas Indonesia.

Paweenawat, S. W., \& Vechbanyongratana, J. (2015). Private returns to STEM education in Thailand. Retrieved from https://core.ac.uk/download/pdf/211617 384.pdf.

Purnastuti, L., Miller, P. W., \& Salim, R. (2013). Declining rates of return to education: Evidence for Indonesia. Bulletin of Indonesian Economic Studies, 49(2), 213-236. doi: 10.1080/ 00074918.2013 .809842$.

Ranti, F. G. (2015). Pilihan bersekolah dan tingkat pengembalian investasi pendidikan menengah di Indonesia (Analisis data SUSENAS 2013). Tesis. Program Pascasarjana Multidisiplin Kajian Kependudukan dan Ketenagakerjaan, Universitas Indonesia.

Ray, R. (2015). STEM education and economic performance in the American States. MPRA Paper 65517. Retrieved from https://mpra.ub.uni-muenchen.de/ 65517/.

Ristekdikti. (2017). Persyaratan dan prosedur pendirian dan perubahan perguruan tinggi swasta serta pembukaan dan perubahan program studi pada perguruan tinggi periode 2 tahun 2018. Retrieved from http://kopertis3. or.id/v2/wp-content/uploads/BukuPersyaratan-dan-Prosedur-Pendiriandan-Perubahan-PTS-serta-Pembukaandan-Perubahan-Prodi-pada-PT-PeriodeI-Tahun-2018.pdf.

Roberts, A., \& Cantu, D. (2012). Applying STEM instructional strategies to design and technology curriculum. PATT 26 Conference: Technology Education in the 21st Century, 111-118. Retrieved from https://ep.liu.se/ecp/073/013/ ecp12073013.pdf.

Schultz, T. W. (1961). Investment in human capital. The American Economic Review, 51(1), 1-17. Retrieved from https://www.jstor.org/stable/1818907.

Shin, S., Rachmatullah, A., Roshayanti, F., Ha, M., \& Lee, J. K. (2018). Career motivation of secondary students in STEM: A cross-cultural study between Korea and Indonesia. International Journal for Educational and Vocational Guidance, 18(2), 203-231. doi: 10.1007/s10775-017-9355-0.

Smith, E., White, P., Smith, E., \& White, P. (2017). A ' great way to get on '? The early career destinations of science, technology, engineering and mathematics graduates technology, engineering and mathematics graduates. Research Papers in Education, 32(2), 1-23. doi: 10.1080/02671522.2016. 1167236.

Suga, F. (2017). The returns to postgraduate education. ESRI Discussion Paper Series, (336). Retrieved from https:// www.esri.cao.go.jp/jp/esri/archive/e_di s/e_dis336/e_dis336.pdf.

Todaro, M. P., \& Smith, S. C. (2011). Pembangunan ekonomi (Edisi Kesebelas; Alihbahasa: A. Maulana \& N. I. Sallama). Erlangga.

UNESCO. (2007). Science, technology and gender. Retrieved from https://unesdoc. unesco.org/ark:/48223/pf0000154045.

VeteransAffairs. (2020). STEM designated degree program list. Retrieved from https://benefits.va.gov/gibill/docs/fgib/ STEM_Program_List.pdf.

Walker, I., \& Zhu, Y. (2011). Differences by degree: Evidence of the net financial rates of return to undergraduate study for England and Wales. Economics of Education Review, 30(6), 1177-1186. doi: 10.1016/j.econedurev.2011.01.002.

Wang, X. (2013). Why students choose STEM majors: Motivation, high school learning, and postsecondary context of 
support. American Educational

Research Journal, 50(5), 1081-1121. doi: 10.3102/0002831213488622.

Webber, D. A. (2014). The lifetime earnings premia of different majors: Correcting for selection based on cognitive, noncognitive, and unobserved factors. Labour Economics, 28(4), 14-23. doi: 10.1016/j.labeco.2014.03.009. 